\title{
Governing Globalization. The Role of Europe for a Stable Monetary System and Sustainable Trade.
}

\author{
Antonio Mosconi
}

\section{Globalizationis thenew"modeof production"}

Globalization is a very complex phenomenon. We could not understand it and evaluate the extent of its consequences without resorting to Marx's concept of mode of production, which even the most pragmatic economists use without even mentioning it. One of the brightest examples is Richard Baldwin (The Great Convergence, 2016). ICT has cut down the costs that separate the place of production from that of consumption.

- After the agricultural revolution, the world has remained motionless until around 1820, when the effects of the industrial revolution began to become apparent (Maddison).

- In the first phase of industrialization, all three of these costs (ICT) were high, so the places of production and consumption could not be distant from each other and the advantages of the industrial revolution were concentrated in the places where it first took place. Thus a "great divergence" has been produced between the industrialized countries and the others. China stopped at 1820 and only in the last decades has it reacquired its previous clout in the world.

- The reduction in transport costs has allowed the development of international trade in the form known during the pax Britannica era: raw materials from the colonies against artifacts in the motherland, but the factories remained close to the places of origin of the knowhow, because the transfer of technologies was expensive.

- Only the ICT revolution, allowing to manage factories located where the cost of labor is lower, has initiated a technology transfer to the emerging countries. Thus, global value-chains have developed in which, at the beginning, the most profitable phases (research, design, marketing and distribution) remain in developed countries, while production is decentralized where its costs are lower.

- The "great convergence" is finally realized when the emerging countries reach the conditions to attract the relocation of the most profitable phases of the processes and / or to develop them autonomously.

These are developments of capitalism that Marx had already foreseen almost two centuries ago and which today lead Lucio Levi to correctly define the current one as the scientific revolution and not as the third industrial revolution. The scientific level reached by the production activities of goods and services (including financial algorithms, weapons of mass destruction for savings, but one of the most important "productive" capitals in the financial industry) makes it so that capital is ever less physical (factories) and increasingly incorporated into our individual and collective knowledge-level (the general intellect of Marx' Gründrisse, i.e. science). 
The expansion dynamics of capitalism tends to bring investments in every sector of the economy to every corner of the globe. External diseconomies, e.g. environmental plundering and degradation, climate change, etc., are charged to the community. Public goods (public property) and common ones (non-competitive and indivisible) are perishing. Merit goods (education, health care, social security, culture) no longer enjoy sufficient support on the part of general taxation. The private sector blooms while the public sector dies. Poverty increases with wealth, exclusion with inclusion. The labor market is polarized. Deflation affects all prices, including wages and interest rates. Profits increase, but are not reinvested. The "liquidity trap" can be measured in corporate treasuries. Only in Europe, five trillion euros are liquid in nonfinancial companies. $70 \%$ of the liquidity of American companies remains in tax heavens. Big companies invest in buying their own shares, i.e. to liquidate assets, raise stock prices and the stratospheric remuneration of managers (stock-options). At the same time, indebtedness is the new form of slavery.

A colossal mis-matching between supply (of private and luxury goods) and demand (of public, common, merit and intergenerational goods) seems evident. His ecological unawareness prevented Schumpeter from taking due account of external diseconomies. So he built his theory of profit on "creative destruction", the incessant replacement of products, technologies, markets and organizations with more profitable ones. In reality, the rate of global profit is kept close to $3 \%$ over the long term, thanks to the privatization of natural monopolies, to the formation of monopolies and oligopolies, to the States-insurers that socialize losses, to wars and to the impoverishment of collective resources. Private profits correspond to public losses. Destruction is not creative. There is thus a senseless distortion in the allocation of resources, that must be remedied through the internalization, through taxation, of external diseconomies. In order for market prices to signal the real scarcities, all the costs which are not accounted for by the companies because they are paid by the community must be included in the cost of the product. For this reason, looking at the current emergencies, we federalists support the need for two taxes at the European federal level: a carbon tax and a tax on financial transactions. With the first, the "who pollutes, pays" principle is introduced, with the second, part of the costs periodically borne by the States for financialcompanies bailouts are brought back to the financial system.

These taxes should be raised at the global level, to finance the UN, but shall be raised at least at the level of regional federations, to prevent them from becoming a weapon in the competition between national states, and allow a more effective and efficient investment of revenues. But politics (national) is subordinated to economic and financial power (global): an unequal game that generates a competition downward in all public functions and an increasingly disquieting imbalance between the immeasurable dimension of consumption and private wealth, and the poverty of essential public goods. To solve problems of this magnitude, cooperation between the largest and most responsible regions of the world, within international organizations, is indispensable.

2. The raison d'état corresponding to the global mode of production is international cooperation

Only federalism satisfactorily addresses the 21 problem of the relationship between the 
mode of production and the raison d'état. As long as the latter prevails, democracy is incomplete because it is mutilated by the primacy of foreign policy (bringing about wars, massacres, state secrets).

Even when they come to realize the contradiction between the global mode of production and the national political dimension (as already happened at the European level), rulers and scholars, victims of methodological nationalism, do not clarify the problem of the world organization of power. They thus propose wrong solutions in opposite directions:

- on the one hand, the populist and / or sovereign right and other similar groups, even of the left, call for the restoration of the exclusive power of the national states, that is, the absolute primacy of the raison d'état. This policy would push back the development level of the productive forces into the enclosure of national cages, and would make war more probable (the scenario of the 1930s);

- on the other hand, for the American neoliberalists the market is self-regulating and the States must have minimal dimensions, except the United States of course, because eventhemarketdoesnotexistwithouta State that institutes it, protects it and sanctions its contracts. But the United States has failed both as a world gendarme and as a world banker. Neo-liberalism has masked the project of the unipolar American rule after the cold war, has increased international anarchy and, as already did the sovereigntycentered populism between the two wars, has been the cause of many conflicts. All of them lost by the United States (the State, its tax-payers, the holders of dollars), but not by the lords of war, it too privatized (see Halliburton).

Both these ideologies, unlike federalism, do not have peace as a principle and do not recognize that the structural rebalancing between the great regions of the world has made it impossible for the national states or for a hegemonic power to govern it. Contrary to what Trump says, we need to give greater force, through democratic legitimacy, and greater effectiveness, through reforms and simplifications, to the United Nations system. Two organizations, IMF and WTO, are potentially equipped for the governance of the world economy. They were designed, even before the end of WWII, by the United States. But the US no longer supports them since other protagonists asked to take part in their control. It is now up to Europe, with China, the emerging countries, the potential great federations and the residual American democratic pressure, to demonstrate how the IMF and the WTO can become real instruments of cooperation and no longer a mask of the world power of a single hegemonic State. This task could hardly be fulfilled in the absence of a European initiative. On the other hand, Europe could not become a "gentle power" (Tommaso Padoa-Schioppa) if it does not come to grips with that task, because in a divided and war-prone world it would be forced to act according to the European raison d'état and centralize power to govern the state of war, as happened in the United States for its pursuit of the imperial project corresponding to its"exceptionalism".

A Europe-fortress, Europe Puissance or Fourth Reich not only represents the opposite of a federal democracy, to the construction of which we have dedicated our lives, but contradicts the "raison d'état" of Europe's world primacyin establishing a governed commercial openness.

3. The multi-currency system requires an international currency (SDR)

The wars in Western Asia and the financial crisis of 2007-2008 marked the end of the 
American attempt to achieve the global supremacy. Global public goods such as security and monetary and financial stability are no longer guaranteed by the United States. This opens up the possibility of cooperation between vast regional areas, and create a new world order through the reform of the Bretton Woods institutions, the progressive institutionalization of the current governance instruments, and the democratic reform of the United Nations.

From the 1920s to the 1960s, the dollar has been the currency of the creditor power. From the seventies onwards it is the currency of a country whose international debt grows in a geometric progression. The dollar can no longer function as the only international currency, while it can maintain a regional status.

The spontaneous transition of the monetary system from the dollar standard to a multicurrency regime, started with the introduction of the ECU, later the euro, and continued with the internationalization of the renmimbi, can cause instability if it is not directed towards the creation of a world currency.

As happened in the EU, also in the relations between the great regions of the world a currency must be established that is independent of the interests of a single state. At the beginning it can be a basket, the one that already exists: the Special Drawing Right (SDR) of the IMF, created by Triffin.

The entry of the renmimbi among the currencies that make up the SDR was decided by the G20 of London, in 2009, after the Lehmann Bros. bankruptcy, but has been frozen by the US Congress until 2015. Along with the reform of the quotas and voting rights in the Fund, it is one of Obama's most important legacies. It has increased the capacity and legitimacy of the SDR to represent the world economy. However, it retains the veto right of the United States, which was understandable in 1946, but is now disproportionate to its relative weight in the world economy.

In 2016, as soon as the entry of the renmimbi into the SDR basket was completed, the World Bank announced an agreement with the People's Bank of China to issue a two billion SDRs loan (amounting to 2.8 billion dollars) on the Chinese domestic market, payable in renmimbi.

The Robert Triffin International foundation, created and led by Alfonso Iozzo, has made an important contribution to these advances towards an international currency, and today it works to consolidate the ground for the use of SDRs by the market, on the path opened by the World Bank. A territory, the world market, where Trump does not enjoy veto rights. It is necessary to issue European and Chinese safe assets, comparable to the American Treasury Bonds, and to create a technical and legal infrastructure for the clearing of deposit and securities positions. It would be enough that the banks operating on the SDR market, as already done by the banks that promoted the ECU, entrust its management to the Bank for International Settlements (BIS, a legacy of Paul Warburg, like the Fed).

4. International trade and the democratization of the WTO.

Before the Second World War ended, the United States defined the architecture of the post-war world economic system. Freedom of trade and monetary stability were considered inseparable, so the pillars of the new world were the GATT (General Agreement on Tariffs and Trade) and the Bretton Woods Agreements. In Europe, thanks to the federalist Beveridge, it was understood that a third pillar was necessary for the stability of the system: the Welfare State.

The establishment of the dollar as the international currency (in particular for fixing 


\section{Comments}

the oil price), the American veto right in the IMF, the managing of the World Bank, the "double standard" which became the rule in the GATT in commercial matters (that is, an application of rules advantageous for the United States), were the backbone of the economic system that, together with its military supremacy, brought about the American hegemony.

We are witnessing now the decline of the relative weight of the United States in the world, the emergence of regional quasifederations, the growing contribution of emerging countries to the world product and development, the consequent pressure for a reform of international organizations to reflect the world as it exists now and not the one imposed by the military, political and economic force-relations of 1945.

The world economic order can only be reconstituted by restoring at the world level the three pillars for world balance already identified during the war: freedom of trade, the welfare state and monetary stability. To be ruled, however, with the method of international cooperation and not with that of the domination of a single country. Trade and currency are the two sectors on which the EU has exclusive competence. The democratization of the WTO and the unitary representation of the EU in the IMF are therefore the first possible steps in the right direction, following the lesson of Jean Monnet. 